\title{
QUIXOTE
}

\section{E SEU CAVALO}

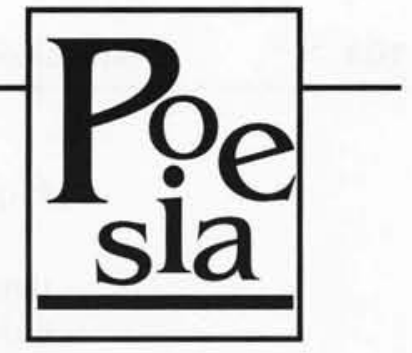

\section{(À memória de Sergio Martinez Sopeña, escultor cubano)}

Me verão, muito magro, na rua Vinte e Três

um rocinante a mais, morto de fome de aventuras.

Meu amo se oxida em nostalgias

enquanto eu sigo, imóvel sempre e andarilho

olhando os homens com suas calças inúteis

e as mulheres de nádegas de bronze.

Os cães sabem de mim. Buscam seus pães e aspiram

o ar que me circunda na tarde dissipada.

Eu só, que bebo ferro, eu sigo alimentado;

passam por mim os distúrbios da fome

como passaram as loucuras de ontem.

Sei que o mar me responde para lá da

amurada.

Ouvi dizer que outro moço patrício

preferiu ofertar-se. Eu espero no tempo.

Virá. São sete séculos.

Nem um minuto

menos.

Pessoas dizem coisas, depois voltam a

dizê-las

depois dizem que não, não foram elas.

É duro ser inteiro e ter grãos, como eu tenho. Inda que velho, respondo pelo meu silêncio.

A AUTORA
Renata Pallottini
Dramaturga, poetisa e Professora Doutora em Ar-
tes, chefe do Departamento de Artes Cênicas da
ECA/USP; autora, entre outros, de: Casa e outros
poemas (1958); A faca e a pedra (1965);
Escorpião de Numância (1969); Mate e a cor da
viuvez (1975); Coração americano (1979);
Cantar meu povo(1980); Mistério do esqueleto
(1985); Tita, a poeta (1989); Introdução à dra-
maturgia (1983); Dramaturgia. A construção
do personagem (1989); Nosotros (1994); Obra
poética (1995).


É que a dor dói nos ossos e na pele

e é difícil sustentá-la,

também existe o medo de perder os andrajos

e o medo de descer as escadas, e o medo

de perder simplesmente a impressão de liberdade.

Diz Sancho que é prudente jamais assomar-se

que, cabeça, há só uma em cima do pescoço,

e que o homem não é mais homem, quando morto.

Eu digo Viva a Vida e Morra a Morte;

não há nada melhor que ser, quando se pode.

Se a mim me coube um amo, foi por meu nascimento, irracional, quadrúpede incoerente.

Repito as névoas da manhã e ouço as falas da foice sangrando a terra outra vez. Nada é nítido.

$\mathrm{O}$ destino do vivo é viver; e os meninos

exibem roupas e precários lenços

enquanto as mães, cozinhando raízes,

esperam o dia em que retorne o vento.

Ninguém dirá de mim como do outro: Cavalo Louco.

Eu tive meus momentos, e isso que sou inteiro.

Meu passo é lento, mas meu pensamento

disfarça a noite quando passam estrelas.

As rédeas ladeadas já não me conduzem.

Don Alonso quedou-se. Em seu estômago há uma cruz.

Pousam pássaros mansos na minha cauda de escamas.

$\mathrm{O}$ ferro tem propriedades estranhas.

E comigo é preciso falar de ervas;

assim somos. Perdi meu tempo e estou eterno.

Nada como um cavalo frente ao mar,

este céu tão fechado e tão aberto.

Sou do tempo da palha e dos tambores, comia às vezes como o povo agora.

Sobrevivi; sou lenda; e me desfaço

sob a chuva de outono, ao som de passos. 
Vejo o dia passar e ouço o rumor das rixas por um punhado de cenouras ou de espigas de milho.

Um cavalo, a despeito, tem o seu orgulho. Eu não pude escolher nem dei vivas a nada. Levantei a cabeça e abanei a cauda e me pus a cagar, como é meu hábito.

Um cavalo é assim, mais sua natureza. Mudam-se os nomes e a aveia do banquete. A longa vida faz virar-se a mesa, as espadas guardadas estão verdes.

Ouvi dizer que comer não é tudo, mas me parece bom que nos fartemos. Eu, que carrego o eterno sonho do Homem, mastiguei muitos campos e bebi muitas fontes: não se pode viver sem horizontes.

Um cavalo, que vai e volta devagar, conhece sua razão de regressar.

As águas da cidade fenecem como cinzas. No coração dos homens o tédio se espreguiça.

Às vezes chega alguém que nos toca, abismado: o metal the responde em quatro campanadas, o escudo de meu amo, a minha cauda, soamos a sino os dois, no agouro desta praça...

Aqui ninguém se fala no âmbito das salas, aqui ninguém se fala.

A antiga, a primogênita, a escolhida dizem que foi votada ao fundo oceano. $\mathrm{E}$ os negros fugitivos de outras ilhas talvez a busquem por desejo antigo, talvez a busquem por desejo arcano.

Entre as flores e os pássaros sem sombra os lírios prestes a submergir e o açúcar das folhas, deve haver um conluio: por isso é que hoje a rua está escura. 
Porém o incêndio já se está formando um fogo largo à procura de ambiente, um desespero ardente, fustigado, que diz de medo e ódio entre os irmãos.

Eu sei: a pedra é a pedra.

A guerra é outra palavra.

Há muitos fabricantes de medalhas, mas um artista é preciso pra que se faça uma estátua.

Uma folha caminha a meus pés com paciência. Uma folha-animal se arrasta, presa ao seu elemento. Não se pode esquecer as pequenas verdades, tais como o ser, o pensamento, e um cigarro

Uma folha caminha, disfarçada de folha.

No entanto, olhando bem, é uma verdade com sua força. 